\title{
Textural and Sensory Properties of Pork Jerky Adjusted with Tenderizers or Humectant
}

\author{
Gap-Don Kim³, Eun-Young Jung ${ }^{3}$, Hyun-Woo Seo ${ }^{3}$, \\ Seon-Tea Joo ${ }^{1,2}$, and Han-Sul Yang ${ }^{1,2, *}$ \\ ${ }^{1}$ Department of Animal Science, Gyeongsang National University, Jinju, Gyeongnam 660-701, Korea \\ ${ }^{2}$ Institute of Agriculture and Life Science, Gyeongsang National University, Jinju, Gyeongnam 660-701, Korea \\ ${ }^{3}$ Division of Applied Life Science (BK21 Program), Gyeongsang National University, Jinju, Gyeongnam 660-701, Korea
}

\begin{abstract}
This study was carried out to investigate the textural and sensory properties of pork jerky with differently added sources of tenderizer or humectant at final concentrations of 2 or $5 \%(\mathrm{v} / \mathrm{w})$. Pork jerky treated with $5 \%$ glycerol, kiwi, or pineapple had lower moisture content and water activity than that of control pork jerky $(p<0.05)$. The addition of tenderizer or humectant resulted in a lower shear force than that of control $(p<0.05)$. The addition of 2 or $5 \%$ glycerol resulted in higher equilibrium moisture content (EMC) than other treatments, and addition of tenderizer or humectant produced a higher EMC than that of control $(p<0.05)$. Furthermore, addition of pineapple and kiwi to the samples affected the structures of the myosin heavy chain and the actin filaments of myofibrillar protein, respectively. Trained panel sensory evaluations indicated that pineapple enhanced the flavor score, whereas tenderness score was improved by the addition of tenderizer or humectant $(p<0.05)$.
\end{abstract}

Key words: pork jerky, tenderizer, humectant, texture, sensory property

\section{Introduction}

Jerky is made from sliced whole muscles which have been marinated and dried. It is relatively simple to process, with a typical flavor, and usually requires no refrigeration during commercial distribution, due to low water activity $\left(\mathrm{a}_{\mathrm{w}}\right)$. Jerky products can be made with various marinade techniques, meats from different species and drying conditions (Han et al., 2007; Pegg et al., 2006; Yang et al., 2009). To achieve stability, jerky is dried to $\mathrm{a}_{\mathrm{w}}$ 0.70-0.85 (Quinton et al., 1997) and is shelf-stable at a 0.75:1.00 moisture protein ratio. Also, efficacy of the jerky making processes in inactivating foodborne pathogens has been evaluated by several researchers. For example, Harrison et al. (1997) have studies inactivation of selected pathogens in whole muscle and have determined that allowing the product to reach an internal temperature of $71.1^{\circ} \mathrm{C}$ prior to drying at $60^{\circ} \mathrm{C}$ inactivates

\footnotetext{
*Corresponding author: Han-Sul Yang, Department of Animal Science, Gyeongsang National University, Jinju 660-701, Gyeongnam, Korea. Tel: 82-55-751-5515, Fax: 82-55-7567171, E-mail: hsyang@gnu.kr
}

pathogens that could pose a health hazard to consumers. However, whole muscle jerky is very lean, and may be too dry, or brittle, and may have the undesirable color typical of over-dried meats (Miller et al., 1996). Some comminuted jerky-type products have a softer texture, but also high fat and $\mathrm{a}_{\mathrm{w}}$, resulting in activation of lipid oxidation and microorganism (Quinton et al., 1997).

Tenderness is the main factor which contributes to the overall eating quality of meat (Mori et al., 2001) and is considered to be the most important factor by the average consumer in many countries. The jerky's texture can be altered by the moisture content, as is done for other intermediate moisture (IM) meats (Farouk and Swan, 1999). One such item under development is a shelf stable jerky product, in which $\mathrm{a}_{\mathrm{w}}$ is controlled by adjustment of moisture and the incorporation of glycerol (Barrett et al., 1998). Several studies were undertaken to determine the effect of glycerol on properties of IM meat. Guilbert et al. (1981) found that the addition of 5\% glycerol was effective in reducing $a_{w}$. Textural effects can be obtained by the adjustment of either water or glycerol levels, as both substances can potentially plasticize the protein matrix (Barrett et al., 1998). Lowering $\mathrm{a}_{\mathrm{w}}$ by reducing moisture 
content will produce harder meat products, but the incorporation of glycerol and sorbitol will assist in controlling the $\mathrm{a}_{\mathrm{w}}$ as well as texture. Leung et al. (1984) pointed out that the shelf-life of IM food can be prolonged by the incorporation of sorbitol and will assist in controlling $\mathrm{a}_{\mathrm{w}}$.

Some plant proteolytic enzymes, such as papain, bromelain and ficin, have been widely used as meat tenderizers for food processing (Dransfield and Etherington, 1981; Iizuka and Ashima, 1999). Ashie et al. (2002) reported the relative effects of a $5 \%$ added papain on meat proteins, including that it may improve tenderness in beef. Studies have shown that meat tenderness is mainly associated with the structural integrity of myofibrillar and connective tissue proteins (Marsh and Leet, 1966; Nishimura et al., 1995). Actidin is a plant thiol proteinase which is present in the fruits of the Chinese gooseberry or kiwi fruit (Kamphuis et al., 1985). The market for tenderizers is still rather small, with an inability to control the activities of currently used tenderizers. Also, dried pork jerky with the addition different tenderizers may have altered texture and sensory properties compared to non-tenderizer-added jerky samples.

Therefore, this experiment was aimed to establish the allowable limits of different tenderizers or humectant such as kiwi, pineapple, glycerol and sorbitol to be utilized in dried pork jerky, from texture and sensory point of view.

\section{Materials and Methods}

\section{Preparation of dried pork jerky samples}

The muscle (m.semimembranosus) of fresh pork was purchased from a local processor at $48 \mathrm{~h}$ postmortem. All subcutaneous, intermusclar fat and visible connective tissue were removed from the fresh muscles. After dissection, all muscles were frozen and stored at $-20^{\circ} \mathrm{C}$ until use (within $2 \mathrm{~d}$ ). The frozen pork was thawed at $4^{\circ} \mathrm{C}$ over- night, sliced into pieces of $0.5 \mathrm{~cm}$ thickness with a meat slicer (HFS 350G, Hankook Fugee Industries Co. Ltd., Seoul, Korea) and cut into cubes of $10.0 \times 4.0 \times 0.5 \mathrm{~cm}$. Sliced muscles were cut parallel in direction to muscle fibers. The pork jerky was produced according to the following recipe from Yang et al. (2009). Curing ingredients (based on raw meat weight) were bought from a local food additives plant included salt, sugar, sodium nitrite (Kukje chemical Co., Busan, Korea), sodium erythorbate (Hyupsung Co., Busan, Korea), glycerol (Seojinchem, Ulsan, Korea), D-sorbitol (Roghette, Ulsan, Korea), kiwi and pineapple. Kiwi used in this study was of the Hayward variety grown in the Gyeongnam and pineapple (Ananas comosus L. Merryl) was obtained from Philippine. Kiwi and pineapple were ground through a $5 \mathrm{~mm}$ plate and homogenated at 5,000 rpm for $60 \mathrm{sec}$ using a homogenizer (GG-22, NSF Korea). Kiwi and pineapple juices were obtained after filtering the solid ingredients off of homogenates, respectively. Samples were cured with $1.5 \%$ salt, $1.0 \%$ sugar, $0.02 \%$ sodium nitrite and $0.03 \%$ sodium erythorbate, added with glycerol, sorbitol, kiwi or pineapple made at levels of 2 or $5 \%(\mathrm{v} / \mathrm{wt})$. Nine different treatments were prepared: 1) non-added control, 2 ) added $2 \%$ liquid glycerol, 3 ) added $5 \%$ liquid glycerol, 4) added $2 \%$ liquid sorbitol, 5) added 5\% liquid sorbitol, 6) added $2 \%$ kiwi juice, 7 ) added $5 \%$ kiwi juice, 8 ) added $2 \%$ pineapple juice, and 9 ) added $2 \%$ pineapple juice (Table 1). For each batch of muscle samples and other ingredients were cured thoroughly at $4^{\circ} \mathrm{C}$ for $24 \mathrm{~h}$. All cured muscle samples were dried using a dryer (DS80-1, Dasol Scientific Co. Ltd., Hwaseong, Korea) at an internal temperature of $70^{\circ} \mathrm{C}, 70 \%$ to $40 \%$ relative humidity for $8 \mathrm{~h}$. Samples were then taken for water activity, to a target $\mathrm{a}_{\mathrm{w}}<0.85$. There was adequate air distribution between samples received the same drying treatment. After drying and cooling to ambient $\left(\approx 25^{\circ} \mathrm{C}\right)$ temperature jerky samples were loosely packed, without vacuum, in water im-

Table 1. Formula of pork jerky treated with tenderizers or humectant

\begin{tabular}{|c|c|c|c|c|c|c|c|c|c|}
\hline \multirow[b]{2}{*}{ Ingredients } & \multicolumn{9}{|c|}{ Treatments } \\
\hline & Control & $\begin{array}{c}2 \% \\
\text { glycerol }\end{array}$ & $\begin{array}{c}5 \% \\
\text { glycerol }\end{array}$ & $\begin{array}{c}2 \% \\
\text { sorbitol }\end{array}$ & $\begin{array}{c}5 \% \\
\text { sorbitol }\end{array}$ & $\begin{array}{l}2 \% \\
\text { kiwi }\end{array}$ & $\begin{array}{l}5 \% \\
\text { kiwi }\end{array}$ & $\begin{array}{c}2 \% \\
\text { pineapple }\end{array}$ & $\begin{array}{c}5 \% \\
\text { pineapple }\end{array}$ \\
\hline Salt & 1.5 & 1.5 & 1.5 & 1.5 & 1.5 & 1.5 & 1.5 & 1.5 & 1.5 \\
\hline Sugar & 1.0 & 1.0 & 1.0 & 1.0 & 1.0 & 1.0 & 1.0 & 1.0 & 1.0 \\
\hline Sodium nitrate & 0.02 & 0.02 & 0.02 & 0.02 & 0.02 & 0.02 & 0.02 & 0.02 & 0.02 \\
\hline Sodium erythorbate & 0.03 & 0.03 & 0.03 & 0.03 & 0.03 & 0.03 & 0.03 & 0.03 & 0.03 \\
\hline Glycerol & - & 2.0 & 5.0 & - & - & - & - & - & - \\
\hline Sorbitol & - & - & - & 2.0 & 5.0 & - & - & - & - \\
\hline Kiwi juice & - & - & - & - & - & 2.0 & 5.0 & - & - \\
\hline Pineapple juice & - & - & - & - & - & - & - & 2.0 & 5.0 \\
\hline
\end{tabular}


permeable plastic bags (single package). Jerky samples were subjected to analysis of moisture content, water activity, shear force, color, moisture absorption capacity, SDSpolyacrylamide gel electrophoresis and sensory evaluation.

\section{Moisture content and water activity}

Moisture content was determined according to AOAC methods (AOAC, 2000). The total moisture content of 5 $\mathrm{g}$ of finely chopped samples placed in aluminum moisture dishes were determined from their pre-dry and dry weights (dried in an air oven at $100^{\circ} \mathrm{C}$ for $24 \mathrm{~h}$ ) and expressed as the percentage of pre-dry weight and gram of water per gram of dry weight. The moisture content was determined in triplicate on each jerky product.

Three pieces of dry jerky samples from each treatment were selected and cut into small pieces using sharp scissors and homogenized prior to measurement of water activity. The pieces were put into water activity cups, and their water activities were determined with a water activity meter (AQS-2, Nagy messsystem, Germany), which had been calibrated at ambient temperature $\left(20^{\circ} \mathrm{C}\right)$ with distilled water $\left(\mathrm{a}_{\mathrm{w}}=0.999\right)$ and saturated solutions of $\mathrm{NaCl}$ $\left(\mathrm{a}_{\mathrm{w}}=0.756\right)$ and $\mathrm{KCl}\left(\mathrm{a}_{\mathrm{w}}=0.853\right)$.

\section{Texture property}

Texture property was determined using the Instron Universal Testing Machine (Model 3343, US/MX50, A\&D Co., MA, USA). Cross-sections of pork jerky samples as close as practicable to $0.5 \times 4.0 \mathrm{~cm}$ (approximately 2.0 $\mathrm{cm}^{2}$ ) was cut sample for shear force measurements. The cross-sections of samples were placed at a right angle to the blade. Crosshead speed was $100 \mathrm{~mm} / \mathrm{min}$ and full scale load was $10 \mathrm{~kg}$.

\section{Color analysis}

The surface color of the pork jerky samples was measured by the CIE L ${ }^{*}, a^{*}, b^{*}$ system using a Minolta chromameter (Model CR-310, Minolta Co. LTD., Japan) standardized with a white plate $\left(\mathrm{L}^{*}=89.2, \mathrm{a}^{*}=0.921\right.$ and $\left.b^{*}=0.783\right)$. The measurements for each of five replicates were taken. Lightness $\left(\mathrm{L}^{*}\right)$, redness $\left(\mathrm{a}^{*}\right)$ and yellowness $\left(b^{*}\right)$ values were recorded (CIE, 1986).

\section{Moisture adsorption capacity (MAC)}

Water adsorption capacity measurements were conducted using dehydrated pork jerky samples following procedures described by Yang et al. (2007). Prior to dehydration, the samples were prepared with tenderizer or humectant. All samples were then frozen at $-70^{\circ} \mathrm{C}$ (Clean vac 8, Biotron, Korea) and freeze-dried over a 3 to $5 \mathrm{~d}$ period. Dried and ground samples (approximately $1 \mathrm{~g}$ each) were put into polystyrene weighing dishes $(0.0508$ $\mathrm{m}^{2}$, Fisher Scientific Co.) and further dehydrated in a vacuum desiccator over $\mathrm{P}_{2} \mathrm{O}_{5}$ for 5 to $7 \mathrm{~d}$ until constant weight was attained. The dehydrated samples were equilibrated at $25^{\circ} \mathrm{C}$ in sealed chambers over various saturated salt solutions with known relative vapor pressures (RVP); $\mathrm{LiCl}$ (0.11), $\mathrm{KCH}_{3}(0.23), \mathrm{MgCl}_{2}(0.33), \mathrm{K}_{2} \mathrm{CO}_{3}(0.43)$, $\mathrm{Mg}\left(\mathrm{NO}_{3}\right)_{2}(0.53), \mathrm{KI}(0.69),\left(\mathrm{NH}_{4}\right)_{2} \mathrm{SO}_{4}(0.81)$ and $\mathrm{KNO}_{3}$ (0.93). Equilibrium moisture content $\left(\mathrm{g} \mathrm{H}_{2} \mathrm{O} / \mathrm{g}\right.$ solid) was calculated from the weight gain after no further change in weight had occurred. Triplicate samples from each treatment were measured.

\section{SDS-polyacrylamide gel electrophoresis (SDS-PAGE)}

Jerky samples $(2 \mathrm{~g})$ were added to $20 \mathrm{~mL}$ of rigor buffer containing $75 \mathrm{mM} \mathrm{KCl}, 10 \mathrm{mM} \mathrm{K} \mathrm{HPO}_{4}, 2 \mathrm{mM}$ $\mathrm{MgCl}_{2}$, and $2 \mathrm{mM}$ EGTA, pH 7.0 and homogenized with a polytron homogenizer (T25basic, IKA, Malaysia). The homogenate was centrifuged at $10,000 \times g, 4^{\circ} \mathrm{C}$, for 10 $\mathrm{min}$, after which time, supernatant was decanted. Fresh rigor buffer $20 \mathrm{~mL}$ was then added to the pellet and the homogenization $(\mathrm{P} 1)$ was repeated. This process was repeated to obtain P1-P3. The P3 was used for myofibril fractions. SDS-PAGE was performed according to the method of Laemmli (1970). Protein solutions were mixed at 1:1 (v/v) ratio with the SDS-PAGE sample treatment buffer $(0.25 \mathrm{M}$ Tris-HCl pH 6.8, 4\% SDS, $20 \%$ glycerol, $10 \%$ 2-mercaptoethanol, $1 \%$ bromophenol blue) and heated at $100^{\circ} \mathrm{C}$ for $1 \mathrm{~min}$ in a heating block (DigiBlock ${ }^{\circledR} 5402$, ${ }^{\circledR}$ Electrothermal, USA) and applied to the gel. Each samples $(1 \mathrm{mg} / \mathrm{mL})$ was loaded on the gel made of $4 \%$ stacking and $15 \%$ separating gels and subjected to electrophoresis at a constant current of 10-20 mA per gel using a mini-gel electrophoresis unit (Might Small ${ }^{\mathrm{TM}} \mathrm{SE}$ 245, Hoefer Scientific Instruments, USA). After electrophoresis, the gels were stained with $0.1 \%$ Coomassie brilliant blue R-250 in 40\% methanol and 7\% acetic acid and distained with $40 \%$ methanol and $7 \%$ acetic acid. Molecular weights of protein bands were calculated using standard marker (M-0630, Sigma, USA). The density of each band on a gel was measured with a gel documentation analysis system (EDAS 290, Kodak, Japan).

\section{Sensory training and evaluation}

Ten panelists (GNU: Gyeongsang National University students, faculty, and staff) were recruited and trained in 3 training sessions. Ten panelists were screened from 13 
potential panelists using basic taste identification tests. Panelists were given samples representing anchor points for each attribute, and training sessions using pork jerky without tenderizer or humectant (control) and pork jerky with tenderizer/humectant treatments ( 2 or $5 \%$ glycerol, sorbitol, kiwi and pineapple) produced in the GNU meat lab. The samples were evaluated for cooked pork flavor ("5 extremely intense" and "1 slightly intense"), tenderizer or humectant flavor intensity ("5 extremely intense" and "1 slightly intense"), juiciness ("5 extremely juicy" and "1 no juicy"), toughness ("5 very tough, and 1 not tough), and cured color intensity/redness ("5 extremely red" and "1 slightly red"). Final anchor point ratings were decided upon by training panel after initial evaluation and discussion. They were trained with commercial jerky products for 2 weeks (three sessions per week) with the product characteristics to be evaluated. The panelists evaluated the samples for appearance, color, flavor, juiciness, toughness and overall acceptability using a 9-point hedonic scale as described by Meilgaard et al. (1999). The panelists evaluated each characteristic of the sample using a 9point hedonic scale, where one (1) was "dislike extremely" and fifteen (9) was "like extremely." Samples were cut no more than $30 \mathrm{~min}$ prior to the sensory evaluation and pieces were held in zippered plastic bags to prevent drying. The samples were transferred into glass containers [Pyrex (Pyrex, USA)] with plastic cover before the sensory test started. Panelists evaluated samples in isolated booths fitted with a breadbox server.

\section{Statistical analysis}

Data from three replications were analyzed by analysis of variance (ANOVA) using statistical analysis systems (SAS). ANOVA was adapted to designing mathematical model using SAS 8.2 (SAS Institute, Inc., USA). Duncan's multiple range test was used to determine the statistical significance among the means (SAS, 2002) at 95\% significant level.

\section{Results and Discussion}

\section{Moisture content, water activity and shear force}

The moisture content, water activity $\left(\mathrm{a}_{\mathrm{w}}\right)$ and shear force of the pork jerky samples with tenderizers or humectants are shown in Table 1. Pork jerky samples showed significant differences in moisture content and water activity $(p<0.05)$. The samples with $2 \%$ glycerol and 2 or $5 \%$ sorbitol added showed a higher moisture content than the control. On the other hand, those samples to which were added kiwi and pineapple showed significantly lower moisture content than those of the control pork jerky sample $(p<0.05)$; the percentage of moisture content of the pork jerky was affected by the addition of these tenderizer or humectant. Pineapple had slightly less moisture (18.51-19.02\%) than the other treatments and control. In general, jerky texture can be altered by the moisture contents, but jerky manufacturing methods also include extrusion and infusion of meats with tenderizer or humectant to lower $\mathrm{a}_{\mathrm{w}}$ (Chang et al., 1991). Also, commercial IM foods have moisture contents of 20 to $40 \%$ (Jose et al., 1994). Pork jerky is classified as an IM meat product with moisture content of about 20 to $25 \%$ (Chen et al., 2002).

There were significant differences among the $\mathrm{a}_{\mathrm{w}}$ of the pork jerky samples which underwent the same drying conditions. The results of $2 \%$ glycerol and 2 or $5 \%$ sorbitol added to pork jerky samples showed a higher $\mathrm{a}_{\mathrm{w}}$ than that of the control pork jerky sample. However, the water activity of the pork jerky samples was $0.74,0.75,0.74$ and 0.73 for $5 \%$ glycerol, $5 \%$ kiwi, $2 \%$ pineapple and $5 \%$ pineapple, respectively. 5\% glycerol, kiwi and pineapple added pork jerky samples showed significant differences, with lower $\mathrm{a}_{\mathrm{w}}$ than the control pork jerky sample ( $p<$ $0.05)$. In the previous studies, the samples were dried to achieve an acceptable $\mathrm{a}_{\mathrm{w}}$ for proper shelf-life. The shelflife of IM meat products decreases with higher moisture content and $\mathrm{a}_{\mathrm{w}}$, due to inhibition of microbial growth (Gould and Christian, 1988). The final IM products reached a constant $\mathrm{a}_{\mathrm{w}}$ of $0.70-0.75$ and were then ready for consumption, and would normally be shelf-stable for 6 months, unpacked (Torres et al., 1994). Also, Yang et al. (2009) reported that $\mathrm{a}_{\mathrm{w}}$ of dried whole muscle pork jerky varied from 0.794 to 0.822 , which is lower when compared to beef jerky. Glycerol is an effective additive for the control of $\mathrm{a}_{\mathrm{w}}$ (Linko et al., 1985). Barrett et al. (1998) reported that $\mathrm{a}_{\mathrm{w}}$ could be reduced from 0.90 to 0.85 with a $28 \%$ increase in firmness by adding $4 \%$ glycerol. Therefore, it is essential that IM meat products such as jerky should be dried to $\mathrm{a}_{\mathrm{w}}$ acceptable for proper shelflife.

One of the most important attributes of jerky is the hardness, which can be measured as shear force. Shear force values can be used to characterize the IM products and can also define differences in total cutting force. In this study, shear force was defined as the maximum force attained as a blade sheared through pork jerky samples, and the results are shown in Table 1. The addition of tenderizer or humectant produces lower shear force com- 
pared to the control $(p<0.05)$ and $2 \%$ sorbitol added to the samples showed the lowest shear force value compared to all other treatments. The results were identical to those reported by Barrett et al. (1998), indicating that the glycerol can act as an effective textural plasticizer in certain meat products. Chen et al. (2000) reported that the shear force of pork jerky decreased significantly with increased levels of glycerol. The enzymatic tenderization have either been investigated or applied to improve meat tenderness (Cheftel and Culioli, 1997). Our results, however, demonstrated that the softer pork jerky can be made with 2 or $5 \%$ tenderizer or humectant, and changes in quality can be due to lower moisture content and $\mathrm{a}_{\mathrm{w}}$.

\section{Color analysis}

Color of the pork jerky samples with/without tenderizers is shown in Table 2. 5\% glycerol showed a significantly lower lightness $\left(\mathrm{L}^{*}\right)$ than control $(p<0.05)$. These results indicate that the addition of $5 \%$ glycerol is useful in preparing pork jerky which results in a darker processed meat. The addition of glycerol for darker beef stick samples can be produced by increasing the glycerol level (Barrett et al., 1998). Darkening as a result of reduced $a_{w}$ was the only effect discernible by the eye. Several researchers reported enzymatic or non-enzymatic browning in meat, due to the reactivity of fruit or glycerol with protein (Sherwin and Labuza, 2003). However, the addition of sorbitol, kiwi and pineapple did not show a significant difference in $\mathrm{L}^{*}$ compared to the control. The redness $\left(\mathrm{a}^{*}\right)$ of the pork jerky samples differed significantly. The addition of tenderizer or humectant produces higher $\mathrm{a}^{*}$, and the addition of $2 \%$ glycerol, $2 \%$ sorbitol, $5 \%$ kiwi and 2 or $5 \%$ pineapple resulted in a significantly higher $\mathrm{a}^{*}$ than control $(p<0.05)$. The addition of $2 \%$ kiwi

Table 2. Moisture content, water activity and shear force of pork jerky treated with tenderizers or humectant ${ }^{1)}$

\begin{tabular}{|c|c|c|c|}
\hline Treatments & $\begin{array}{c}\text { Moisture } \\
\text { content }(\%)\end{array}$ & $\begin{array}{c}\text { Water } \\
\text { activity }\end{array}$ & $\begin{array}{c}\text { Shear force } \\
\left(\mathrm{kg} / \mathrm{cm}^{2}\right)\end{array}$ \\
\hline Control & $25.57 \pm 1.00^{b}$ & $0.81 \pm 0.01^{\mathrm{c}}$ & $7.14 \pm 0.77^{\mathrm{a}}$ \\
\hline $2 \%$ glycerol & $28.06 \pm 0.49^{\mathrm{a}}$ & $0.83 \pm 0.00^{\mathrm{b}}$ & $4.68 \pm 0.57^{\text {cde }}$ \\
\hline $5 \%$ glycerol & $21.85 \pm 0.31^{\mathrm{c}}$ & $0.74 \pm 0.01^{\mathrm{g}}$ & $4.94 \pm 0.43^{\text {cde }}$ \\
\hline $2 \%$ sorbitol & $27.59 \pm 0.70^{\mathrm{a}}$ & $0.83 \pm 0.00^{\mathrm{b}}$ & $4.14 \pm 0.64^{\mathrm{e}}$ \\
\hline $5 \%$ sorbitol & $27.77 \pm 0.59^{a}$ & $0.85 \pm 0.00^{\mathrm{a}}$ & $4.23 \pm 0.29^{\mathrm{de}}$ \\
\hline $2 \%$ kiwi & $22.42 \pm 0.76^{\mathrm{c}}$ & $0.79 \pm 0.00^{\mathrm{d}}$ & $5.69 \pm 0.65^{\mathrm{b}}$ \\
\hline $5 \%$ kiwi & $21.63 \pm 1.73^{\mathrm{c}}$ & $0.75 \pm 0.00^{\mathrm{e}}$ & $4.97 \pm 0.52^{\text {bcde }}$ \\
\hline $2 \%$ pineapple & $19.02 \pm 0.14^{\mathrm{d}}$ & $0.74 \pm 0.00^{\mathrm{f}}$ & $5.21 \pm 0.72^{\mathrm{bc}}$ \\
\hline $5 \%$ pineapple & $18.51 \pm 0.52^{\mathrm{d}}$ & $0.73 \pm 0.00^{\mathrm{h}}$ & $5.08 \pm 0.49^{\text {bcd }}$ \\
\hline
\end{tabular}

produced higher yellowness $\left(b^{*}\right)$ compare with other jerky samples $(p<0.05)$.

\section{Water adsorption capacity}

To further investigate why the addition of tenderizer or humectant to pork jerky produced lower shear force value, water adsorption measurements were also conducted with samples of the dried pork jerky. The dehydrated samples were prepared with tenderizer or humectant. Fig. 1 represents the moisture adsorption capacity of dehydrated and powdered samples with tenderizer or humectant added, prior to dehydration. As shown in Fig. 1, at low $\mathrm{a}_{\mathrm{w}}$ range $\left(\mathrm{a}_{\mathrm{w}}<0.53\right)$ the equilibrium moisture content $(\mathrm{EMC})$ were at similar values. For example, EMC at $0.93 \mathrm{a}_{\mathrm{w}}$ was 0.40 $\mathrm{g} \mathrm{H}_{2} \mathrm{O} / \mathrm{g}$ solid and $0.34 \mathrm{~g} \mathrm{H}_{2} \mathrm{O} / \mathrm{g}$ solid for samples with $5 \%$ and $2 \%$ glycerol added, respectively. The addition of $2 \%$ and $5 \%$ glycerol to the samples resulted higher EMC than the other samples. Also, the addition of tenderizer or humectant produced higher EMC than the control $(p<$ $0.05)$. Decrease in shear force by the addition of tenderizer or humectant must be due to increased water retention property in response to drying.

\section{SDS-polyacrylamide gel electrophoresis}

The electrophoresis pattern of myofibrillar proteins of

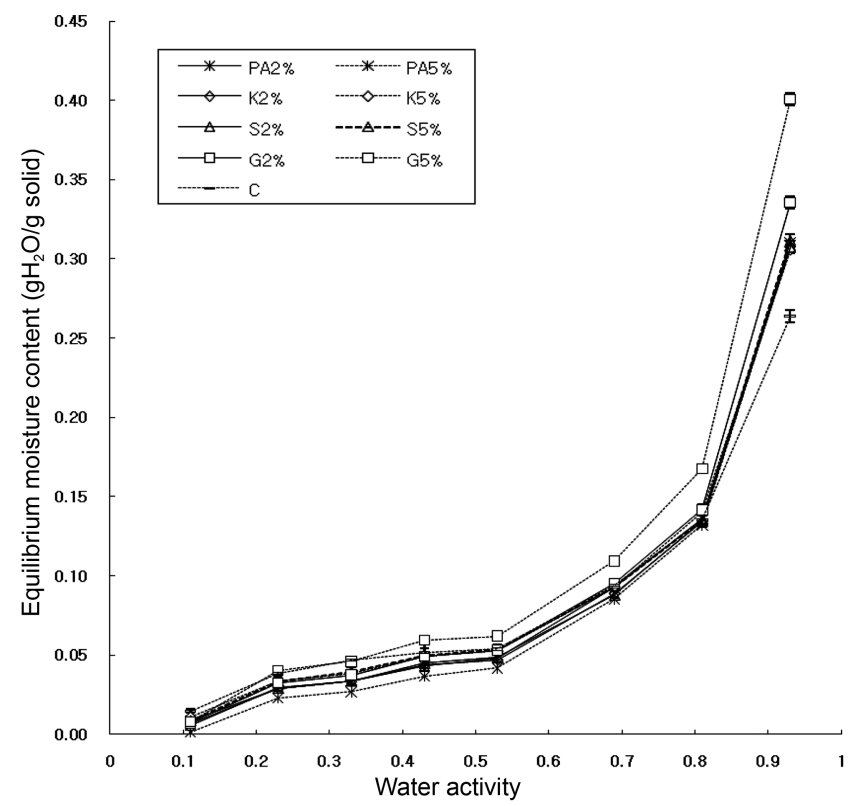

Fig. 1. Moisture adsorption capacity of pork jerky treated with tenderizers or humectant. Control, pork jerky without tenderizer; $\mathrm{G} 2$, treated glycerol $2 \%$; G5, glycerol $5 \%$; S2, sorbitol 2\%; S5, sorbitol 5\%; K2, kiwi 2\%; K5, kiwi 5\%; PA2, pineapple 2\%; and PA5, pineapple 5\%. G, $\mathrm{S}, \mathrm{K}$ and $\mathrm{PA}$ indicate glycerol, sorbitol, kiwi and pineapple, respectively. $n=3$. 
the pork jerky samples with tenderizer or humectant is shown in Fig. 2. According to the SDS polyacrylamide gel patterns, differences in myofibrillar protein fractions among $2 \%$ added treatments (A) could be observed in this study. Probably, because the pineapple sample was more affected by the enzymes present in the pineapple; hence myosin heavy chain of myofibrillar protein was more influenced than other samples. According to the results, 5\% (B) pineapple added sample showed higher degradation of myofibrillar protein (myosin heavy chain, -actidin and actinin) than $2 \%$ pineapple sample. Brooks et al. (1985) reported that the changes of chicken muscle were caused by crude papain treatment using densitometric tracing on SDS gels. According to SDS-PAGE profiles which showed degraded fragments of meat proteins, progress in digestion was clearly observed on both myo-

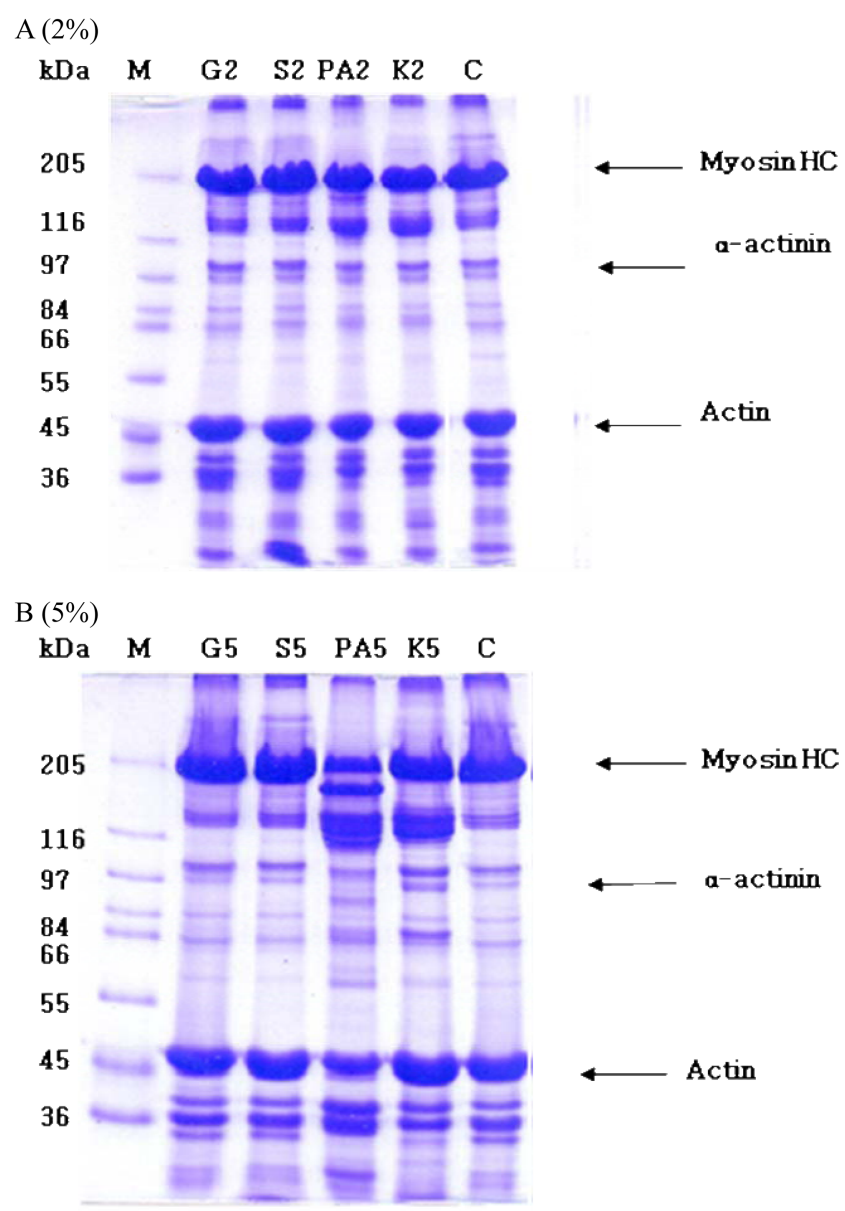

Fig. 2. SDS polyacrylamide gel patterns of myofibril of pork jerky treated with tenderizers or humectant. $M$, denote protein molecular mass standard; Control, pork jerky without tenderizer; $\mathrm{G} 2$, treated glycerol $2 \%$; G5, glycerol $5 \%$; S2, sorbitol 2\%; S5, sorbitol 5\%; K2, kiwi 2\%; K5, kiwi 5\%; PA2, pineapple 2\%; and PA5, pineapple 5\%. G, $\mathrm{S}, \mathrm{K}$ and $\mathrm{PA}$ indicate glycerol, sorbitol, kiwi and pineapple, respectively. $n=3$. sin heavy chain (MHC) and actin, by papain and bromelain, into lower molecular weight fragments with time (Kim and Taub, 1991). Wada et al. (2002) reported that actinidin had fewer disaggregation changes than the actin control. This indicates that the 5\% kiwi sample has higher degradation of myofibrillar protein (myosin heavy chain) than did the $2 \%$ kiwi sample. Furthermore, these enzymes have very broad specificities to break down the major muscle proteins (Miller et al., 1989). These findings indicated that the addition of pineapple and kiwi could affect the structure of the actin and myosin filaments of myofibrillar protein. The results of this study followed the same pattern as in the studies reviewed above.

\section{Sensory evaluations}

The sensory panels were convened to assess the effects on the color, flavor, juiciness, tenderness and overall acceptability of pork jerky samples with tenderizer or humectant (Table 3). Sensory evaluation data of pork jerky indicated that the level and type of tenderizer had an effect $(p<0.05)$ on color, flavor, juiciness, toughness, and overall acceptability. The pork jerky products with $2 \%$ glycerol added produced higher color scores than did the control $(p<0.05)$. Flavor scores were increased by the addition of the tenderizer. The samples with $5 \%$ pineapple added showed higher flavor scores than the control $(p<0.05)$. Toughness scores in the pork jerky products were improved by the addition of a tenderizer or humectant, especially in the samples with kiwi and pineapple $(p<0.05)$. Overall, with regard to the flavor and toughness characteristics, the samples with added kiwi and pineapple had higher likeability scores than did the control pork jerky sample. Chen et al. (2000) demonstrated that Chinese-style pork jerky with glycerol and sorbitol had better

Table 3. Color (CIE $\left.L^{*}, a^{*}, b^{*}\right)$ of pork jerky treated with tenderizers or humectant ${ }^{1}$ )

\begin{tabular}{lccc}
\hline \hline Treatments & $\begin{array}{c}\text { Lightness } \\
\left(\mathrm{L}^{*}\right)\end{array}$ & $\begin{array}{c}\text { Redness } \\
\left(\mathrm{a}^{*}\right)\end{array}$ & $\begin{array}{c}\text { Yellowness } \\
\left(\mathrm{b}^{*}\right)\end{array}$ \\
\hline Control & $37.44 \pm 0.74^{\mathrm{a}}$ & $8.54 \pm 1.65^{\mathrm{b}}$ & $8.34 \pm 1.22^{\mathrm{bc}}$ \\
2\% glycerol & $35.54 \pm 0.99^{\mathrm{ab}}$ & $10.98 \pm 2.02^{\mathrm{a}}$ & $8.07 \pm 0.79^{\mathrm{bc}}$ \\
$5 \%$ glycerol & $31.04 \pm 0.52^{\mathrm{b}}$ & $10.50 \pm 1.98^{\mathrm{ab}}$ & $6.22 \pm 0.91^{\mathrm{c}}$ \\
2\% sorbitol & $34.26 \pm 2.86^{\mathrm{ab}}$ & $10.94 \pm 2.02^{\mathrm{a}}$ & $8.56 \pm 3.13^{\mathrm{b}}$ \\
$5 \%$ sorbitol & $33.26 \pm 2.87^{\mathrm{ab}}$ & $10.12 \pm 1.06^{\mathrm{ab}}$ & $5.81 \pm 0.67^{\mathrm{c}}$ \\
2\% kiwi & $37.78 \pm 5.80^{\mathrm{a}}$ & $9.83 \pm 0.79^{\mathrm{ab}}$ & $12.93 \pm 0.72^{\mathrm{a}}$ \\
$5 \%$ kiwi & $36.18 \pm 0.24^{\mathrm{ab}}$ & $11.09 \pm 1.12^{\mathrm{a}}$ & $10.79 \pm 1.86^{\mathrm{ab}}$ \\
2\% pineapple & $36.21 \pm 3.21^{\mathrm{ab}}$ & $11.34 \pm 2.56^{\mathrm{a}}$ & $10.01 \pm 1.39^{\mathrm{ab}}$ \\
$5 \%$ pineapple & $35.56 \pm 1.17^{\mathrm{ab}}$ & $11.41 \pm 0.55^{\mathrm{a}}$ & $10.37 \pm 0.19^{\mathrm{ab}}$ \\
\hline
\end{tabular}

${ }^{1)}$ Data are expressed as means $\pm \mathrm{SD}, n=3$.

${ }^{\mathrm{a} b}$ Values with different superscripts within a column are significantly different $(p<0.05)$. 
Table 4. Sensory evaluation of pork jerky treated with tenderizers or humectant ${ }^{1)}$

\begin{tabular}{lccccc}
\hline \hline Treatments & Color $^{2}$ & Flavor & Juiciness & Toughness & Overall acceptability \\
\hline Control & $6.10 \pm 1.42^{\mathrm{bc}}$ & $4.00 \pm 2.16^{\mathrm{b}}$ & $5.83 \pm 2.08^{\mathrm{ab}}$ & $3.73 \pm 1.89^{\mathrm{b}}$ & $4.37 \pm 0.57^{\mathrm{d}}$ \\
$2 \%$ glycerol & $7.87 \pm 1.40^{\mathrm{a}}$ & $4.13 \pm 1.40^{\mathrm{b}}$ & $4.87 \pm 0.51^{\mathrm{ab}}$ & $5.27 \pm 0.40^{\mathrm{ab}}$ & $4.70 \pm 0.60^{\mathrm{cd}}$ \\
$5 \%$ glycerol & $6.03 \pm 0.35^{\mathrm{bc}}$ & $5.43 \pm 1.12^{\mathrm{ab}}$ & $4.00 \pm 0.55^{\mathrm{b}}$ & $5.17 \pm 0.47^{\mathrm{ab}}$ & $5.63 \pm 0.60^{\mathrm{bcd}}$ \\
$2 \%$ sorbitol & $6.37 \pm 0.40^{\mathrm{abc}}$ & $5.60 \pm 0.66^{\mathrm{ab}}$ & $5.33 \pm 0.91^{\mathrm{ab}}$ & $5.77 \pm 0.59^{\mathrm{ab}}$ & $5.93 \pm 0.12^{\mathrm{abcd}}$ \\
$5 \%$ sorbitol & $5.87 \pm 0.96^{\mathrm{bc}}$ & $5.50 \pm 0.75^{\mathrm{ab}}$ & $5.20 \pm 1.01^{\mathrm{ab}}$ & $5.80 \pm 0.70^{\mathrm{ab}}$ & $6.10 \pm 0.61^{\mathrm{abcd}}$ \\
$2 \%$ kiwi & $5.00 \pm 0.10^{\mathrm{c}}$ & $5.57 \pm 0.67^{\mathrm{ab}}$ & $5.60 \pm 1.02^{\mathrm{ab}}$ & $6.70 \pm 1.25^{\mathrm{a}}$ & $6.47 \pm 0.45^{\mathrm{abc}}$ \\
$5 \%$ kiwi & $5.50 \pm 0.46^{\mathrm{bc}}$ & $5.23 \pm 1.70^{\mathrm{ab}}$ & $5.77 \pm 1.37^{\mathrm{ab}}$ & $6.97 \pm 1.46^{\mathrm{a}}$ & $5.80 \pm 0.66^{\mathrm{bcd}}$ \\
$2 \%$ pineapple & $6.10 \pm 0.78^{\mathrm{bc}}$ & $7.23 \pm 2.64^{\mathrm{a}}$ & $5.93 \pm 1.36^{\mathrm{ab}}$ & $7.27 \pm 1.42^{\mathrm{a}}$ & $7.87 \pm 1.89^{\mathrm{a}}$ \\
$5 \%$ pineapple & $6.83 \pm 1.36^{\mathrm{ab}}$ & $7.53 \pm 1.72^{\mathrm{a}}$ & $6.47 \pm 1.46^{\mathrm{a}}$ & $7.50 \pm 1.8^{\mathrm{a}}$ & $7.23 \pm 2.01^{\mathrm{ab}}$ \\
\hline
\end{tabular}

${ }^{1)}$ Data are expressed as means $\pm \mathrm{SD}, n=3$.

${ }^{2)}$ Based on a 9-point intensity scale (1=dislike extremely or extremely bland/tough/dry/undesirable; 9=like extremely or extremely intense/juicy/tender/desirable).

${ }^{a-b}$ Values with different superscripts within a column are significantly different $(p<0.05)$.

sensory scores for hardness and chewiness when compared to samples without these particular additives. Also, Choi et al. (2008) reported that the instrumentally low shear force and high tenderness of jerky made from ground and restructured meat is a desirable attribute for the consumer. Sensory evaluations indicated that pork jerky with kiwi and pineapple was also well-liked, as were the glycerol and sorbitol jerky samples. Thus, the inclusion of kiwi and pineapple may offer additional natural tenderizers, thereby improving acceptability in dried pork jerky products.

\section{Conclusion}

Results from this study demonstrate that pork jerky with various tenderizer and humectant have less moisture content and lower $\mathrm{a}_{\mathrm{w}}$ than the control sample. Moreover, pork jerky made with treated tenderizer or humectant samples had lower shear force values than the controls. These findings indicated that the addition of pineapple and kiwi affected the structure of the myosin and actin filaments of myofibrillar protein, and with added glycerol samples had the higher EMC than the control. Further research into the sensory evaluation indicated that acceptability of pork jerky could be enhanced by the addition of various tenderizers. In particular, the addition of natural meat tenderizers, such as kiwi and pineapple, result in increased flavor, tenderness and an overall increased acceptability score.

\section{Acknowledgement}

This research was supported by Rural Development Administration (Project No. PJ007259), and G. D. Kim,
E. Y. Jung, and H. W. Seo were supported by scholarship from the BK21 Program, the Ministry of Education, Science and Technology, Republic of Korea.

\section{References}

1. AOAC. (2000) Official Methods of Analysis of the Association of Official Analytical Chemists. 17th ed. Association of Official Analytical Chemists. Gaithersburg, MD.

2. Ashie, I. N. A., Sorensen, T. L., and Nielsen, P. M. (2002) Effects of papain and a microbial enzyme on meat proteins and beef tenderness. J. Food Sci. 67, 2138-2142.

3. Barrett, A. H., Briggs, J., Richardson, M., and Reed, T. (1998) Texture and storage stability of processed beefsticks as affected by glycerol and moisture levels. J. Food Sci. 63, 84-87.

4. Brooks, B. A., Klasing, K. C., and Regenstein, J. M. (1985) Effects of antemortem injected crude papain in chicken muscle. J. Food Sci. 50, 1370-1374.

5. Chang, S. F., Huang, T. C., and Pearson, A. M. (1991) Some parameters involved in production of Zousoon-A semi-dry, long fibered pork product. Meat Sci. 30, 303-325.

6. Cheftel, J. C. and Culioli, J. (1997) Effects of high pressure on meat: A review. Meat Sci. 46, 211-236.

7. Chen, W. S., Lin, D. C., and Chen, M. T. (2002) Determination of quality changes throughout processing steps in Chinese-style pork jerky. Asian-Aust J Anim Sci. 17, 700-704.

8. Chen, W. S., Lin, D. C., Chen, M. T., and Ockerman, H. W. (2000) Improving texture and storage stability of Chinesestyle pork jerky by the addition of humectants. Asian-Aust $J$ Anim Sci. 13, 1455-1460.

9. Choi, J. H., Jeong, J. Y., Han, D. J., Choi, Y. S., Kim, H. Y., Lee, M. A., Lee, E. S., Paik, H. D., and Kim, C. J. (2008) Effects of pork/beef levels and various casings on quality properties of semi-dried jerky. Meat Sci. 80, 278-286.

10. CIE. (1986) Colorimetry Commission International del' Eclairage, Publication CIE 15.2. 2nd ed. Vienna.

11. Dransfield, E. and Etherington, D. (1981) Enzymes in the 
tenderization of meat. In: Enzymes and Food Processing. Birch, G. G., Blankebrough, N., and Parker, K. J. (eds). Applied Science Publishers, London, UK, pp. 177-194.

12. Farouk, M. M. and Swan, J. E. (1999) Boning and storage temperature effects on the attributes of soft jerky and frozen cooked free-flow mince. J. Food Sci. 64, 465-468.

13. Gould, G. W. and Christian, J. H. B. (1988) Characterization of the state of water in food biological aspects. In: Food Preservation by Moisture Control. Seow C. C. (ed). Elsevier, London, UK, pp. 43-56.

14. Guilbert, S., Clement, O., and Cheftel, J. C. (1981) Relative efficiency of various aw-lowing agents in aqueous solutions and in intermediate moisture foods. Lebensm. Wiss. u-Technol. 14, 245-251.

15. Han, D. J., Jeong, J. Y., Choi, J. H., Choi, Y. S., Kim, H. Y., and Lee, M. A. (2007) Effects of drying conditions on quality properties of pork jerky. Korean J. Food Sci. Anim. Res. 27, 29-34.

16. Harrison, J. A., Harrison, M. A., and Rose, R. A. (1997) Fate of Listeria monocytogenes and Salmonella species in ground beef jerky. J. Food Prot. 60, 1139-1141.

17. Iizuka, K. and Aishima, T. (1999) Tenderization of beef with pineapple juice monitored by fourier transform infrared spectroscopy and chemometric analysis. J. Food Sci. 64, 973-977.

18. Jose, F. S., Rafael, G., and Miguel, A. C. (1994) Water activity of Spanish intermediate-moisture meat products. Meat Sci. 38, 341-350.

19. Kamphuis, I. G., Drenth, J., and Baker, E. N. (1985) Thiol protease. J. Molecular Biol. 182, 317-329.

20. Kim, H. and Taub, I. A. (1991) Specific degradation of myosin in meat by bromelain. Food Chem. 40, 337-343.

21. Laemmli, U. K. (1970) Cleavage of structural proteins during assembly of the head of bacteriophage. T4. Nature 227, 680-685.

22. Leung, H. K., Mallock, J. P., Meyer, R. S., and Morad, M. M. (1984) Storage stability of a puff pastry dough with reduced water activity. J. Food Sci. 49, 1405-1409.

23. Linko, P., Kervinen, R., Karppinen, R., Rautalinna, E. K., and Vainionpaa, J. (1985) Extrusion cooking for cereal-based intermediate-moisture products In: Smiatos, D. and Multon, J. L. (eds). Marcel Dekker, New York, USA, pp. 465-479.

24. Marsh, B. B. and Leet, N. G. (1966) Studies in meat tenderness III. The effects of cold shortening on meat tenderness. $J$. Food Sci. 31, 450-459.

25. Meilgaard, M., Civille, G. V., and Carr, B. T. (1999) Sensory evaluation techniques Boca Ration. 3 rd ed. CRC Press. FL. p. 354.

26. Miller, M. F., Davis, G. W., Ramsey, C. B., and Irizarry, H. (1996) Water activity theory and application to food. In: Rockland L. B. and Beuchat L. R. (ed). Marcel Dekker, New York, USA, pp. 295-328.

27. Miller, A. J., Strange, E. D., and Whiting, R. C. (1989) Improved tenderness of restructured beef steaks by a microbial collagenase derived from Vibrio B-30. J. Food Sci. 54, 855-857.

28. Mori, K, Nishimura, T, Yokoyama, T., and Takahashi, K. (2001) Tenderization of heated sliced beef by succinylated glycerol monostearate, a novel meat tenderizer. J. Food Sci. 66, 524-529.

29. Nishimura, T., Hattori, A., and Takahashi, K. (1995) Structural weakening of intramuscular connective tissue during conditioning of beef. Meat Sci. 39, 127-133.

30. Pegg, R. B., Amarowicz, R., and Code, W. E. (2006) Nutritional characteristics of emu (Dromaius novaehollandiae) meat and its value added products. Food Chem. 97, 193-202.

31. Quinton, R. D., Cornforth, D. P., Hendricks, D. G., Brennand, C. P., and Su, Y. K. (1997) Acceptability and composition of some acidified meat and vegetable stick products. J. Food Sci. 62, 1250-1254.

32. SAS. (2002) SAS/STAT software for pc Release 8.2, Cary, N.C., SAS, Inc.

33. Sherwin, C. P. and Labuza, T. P. (2003) Role of moisture in maillard browning reaction rate intermediate moisture foods: comparing solvent phase and matrix properties. J. Food Sci. 68, 588-594.

34. Torres, E. A. F. S., Shimokomaki, M., Franco, B. D. G. M., Carvalho, Jr. B. C., and Santos, J. C. (1994) Parameter determining the quality of charqui, an intermediate moisture meat product. Meat Sci. 38, 229-234.

35. Wada, M., Suzuki, T., Yaguti, Y., and Hasegawa, T. (2002) The effects of pressure treatments with kiwi fruit protease on adult cattle semitendinosus muscle. Food Chem. 78, 167171.

36. Yang, H. S., Choi, S. G., Jeon, J. T., Park, G. B., and Joo, S. T. (2007) Textural and sensory properties of low fat pork sausages with added hydrated oatmeal and tofu as texture-modifying agents. Meat Sci. 75, 293-299.

37. Yang, H. S., Hwang, Y. H., Joo, S. T., and Park, G. B. (2009) The physicochemical and microbiological characteristics of pork jerky in comparison to beef jerky. Meat Sci. 82, 289294.

(Received 2010.5.26/Revised 1st 2010.8.25, 2nd 2010.11.29/ 